
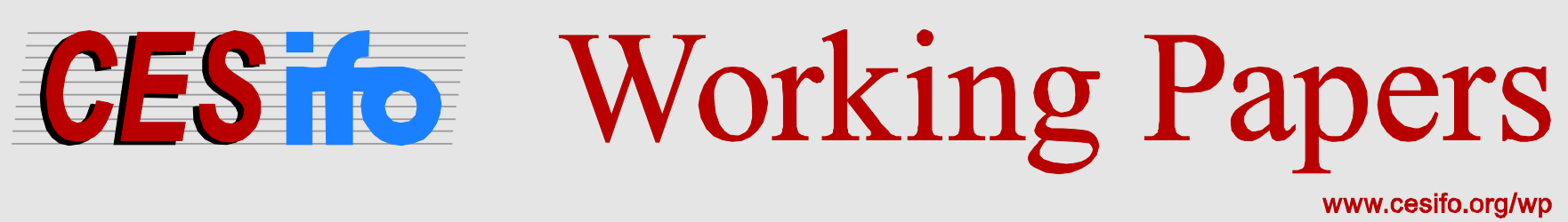

\title{
Does Fiscal Oversight Matter?
}

\author{
Désirée I. Christofzik \\ Sebastian G. Kessing
}

CESIFO WORKING PAPER NO. 5023

CATEGORY 1: PubliC FinANCE

OCTOBER 2014

An electronic version of the paper may be downloaded

- from the SSRN website:

- from the RePEc website:

- from the CESifo website:

www.SSRN.com

www.RePEc.org

www.CESifo-group.org/wp 


\title{
Does Fiscal Oversight Matter?
}

\begin{abstract}
A gradually introduced reform of local government accounting made it temporarily likely for municipalities in the German state of North Rhine-Westphalia to avoid the effective control of their budget by the authorities in charge with overseeing local government budgets and enforcing the existing fiscal rules. Using this arguably exogenous withdrawal of effective fiscal oversight we identify the effects of fiscal restraints and their enforcement on fiscal outcomes. We find that the withdrawal of oversight has a significant and sizeable effect on per capita debt of local governments that were previously constrained by fiscal oversight. Fiscal restraints are important, and oversight and enforcement are key issues for their success.

JEL-Code: H720, H740, R100.
\end{abstract}

Keywords: fiscal oversight, fiscal rules, local government debt.

\author{
Désirée I. Christofzik \\ University of Siegen \\ Department of Economics \\ Hölderlinstrasse 3 \\ Germany - 57076 Siegen \\ desiree.christofzik@uni-siegen.de
}

\author{
Sebastian G. Kessing \\ University of Siegen \\ Department of Economics \\ Hölderlinstrasse 3 \\ Germany - 57076 Siegen \\ kessing@vwl.wiwi.uni-siegen.de
}

18 October 2014

We would like to thank Sascha O. Becker, Marie-Laure Breuillé, Christos Kotsogiannis, Francesco Porcelli and Guido Schwerdt for their comments. Désirée Christofzik gratefully acknowledges the hospitality of the Department of Economics at the University of Exeter. Sebastian Kessing would like to thank the Centre for Competitiveness in the Global Economy (CAGE) at the University of Warwick and the Centre for Business Taxation (CBT) at the University of Oxford for their hospitality. 


\section{Introduction}

Fiscal rules that constrain government debt exist in many countries. In the US, most states follow some form of balanced budget rules and similar provisions exist for local governments in most states. Fiscal restraints have also been in place at the federal level, although typically with a longer time horizon, see Poterba (1996) for an overview and a discussion. In the EU, the establishment of the single currency was accompanied by the introduction of the debt and deficit provisions of the Stability and Growth Pact. More recently, in the aftermath of the European debt crisis, an additional set of fiscal rules to operate at the level of the individual Member States has been implemented, such as the requirement to introduce a numeric budget rule, the so called "debt brake", into national law by 2014. Despite their pervasiveness and the corresponding theoretical debate, see Besley and Smart (2007), Brennan and Buchanan (1980), Drazen (2004), Halac and Yared (2014), and Wyplosz (2012), among others, the empirical evidence on the effects of fiscal restraints on fiscal policy outcomes remains scarce. The empirical analysis has been constrained by the scarcity of appropriate data, and by the challenge to properly identify the effects of fiscal restraints, since their establishment, their stringency and their enforcement are endogenous. Accordingly, much of the existing literature has demonstrated a correlation between fiscal restraints and lower deficits, but, only recently, Grembi et al. (2014), using data on local government in Italy and exploiting the variation of a population discontinuity in the fiscal regulations, have made progress in demonstrating a causal link between fiscal restraints and fiscal policy outcomes.

A key aspect of fiscal restraints is their actual enforcement. Policy makers typically have some scope to circumvent existing restraints, to escape implied sanctions ex post, or even to completely ignore them if there is no legal mechanism to enforce the restraint. Given the recent switch in the EU to a set of more decentralized fiscal rules, it is even more important to understand to what extend fiscal restraints are self-enforcing once in place, or whether they are substantially weakened without proper enforcement. However, despite its importance, the role of enforcement of fiscal restraints has remained even less understood and investigated than the functioning of fiscal rules themselves, see Poterba (1996).

In this study we analyze empirically the implications of a government debt rule and the importance of enforcement and fiscal oversight for local government in the German state of North Rhine-Westphalia (NRW). Within this state a system of fiscal oversight is 
in place to oversee local government budgets. The supervision authorities assess each year whether the municipalities' revenue and spending plans are compatible with the existing balanced budget rule. They assure that local governments comply with the fiscal rule that local governments are not allowed to borrow except for capital investment and to ensure short-term liquidity. Within this setting, which we explain in detail in Section 2.1, we can study quasi-experimental evidence on the oversight process by exploiting an accounting reform that effectively allowed local governments to temporarily escape fiscal oversight. The reform replaced traditional cameralistic public sector accounting (cash accounting) by a system of accrual accounting between 2004 and 2009, but had no fiscal consequences in terms of revenues or expenditures. However, the switch to the new accounting framework allowed many municipalities to temporarily escape effective fiscal oversight, since, upon switching to the new accounting rules, they were granted a fictitious buffer, allowing many of them to "virtually" balance their budgets temporarily. This enables us to properly identify the effect of fiscal oversight, or, more precisely, its absence. Our identification strategy is based on the differences-in-differences method and exploits the fact that the municipalities in NRW implemented the accrual accounting system gradually. While only a few municipalities implemented the reform early on, most municipalities switched during the latter years of the phasing-in period. Accordingly, in the year 2008, a large share of municipalities was already subject to the new rules, and could accordingly virtually balance their budget and avoid potential control by the supervising authorities, but many others were still treated according to the old system and faced the usual scrutiny of the fiscal oversight system. This variation permits us to evaluate the impact on local government debt by comparing those municipalities that were previously subject to oversight, and that were suddenly artificially relieved from oversight by the accounting reform, to those municipalities that continued to be under fiscal oversight. Additionally, we contrast the treatment effect of the withdrawal of oversight for those municipalities where the supervision authorities had previously actively intervened, and those without fiscal restrictions by the authorities before the reform. Thus, because we are able to use arguably exogenous variation that determined whether local governments were subject to fiscal oversight or not, we can properly identify causal effects of fiscal restraints and their enforcement on government debt, in contrast to most of the existing literature.

Our results show that enforcement of fiscal restraints is important. Such constraints are not necessarily self-enforcing once in place in the sense that individual jurisdictions will voluntarily comply with the constraint. Thus, oversight and enforcement of existing 
rules are necessary to guarantee that fiscal restraints operate effectively. Moreover, our results also provide additional support for the importance of fiscal rules themselves. If these did not matter in the first place, oversight and enforcement should be irrelevant. The temporary lifting of oversight results in a significant debt increase. However, this effect is entirely driven by those municipalities that were previously actively restricted by the supervision authorities. For those municipalities that could previously budget completely unrestrictedly or where the proposed budget consolidation plans were greenlighted by the oversight authorities, the temporary absence of effective oversight does not affect the deficit. Finally, the effects are quantitatively important. In our baseline estimations which only consider those municipalities that switched either in 2008 or 2009 we find that local governments that were previously restricted and were assigned a virtual buffer to notionally balance their budget increased their level of short-term debt by EUR 210 per capita in 2008 (average treatment effect). Given that the average per capita level of debt of the group of previously restricted and switching municipalities was EUR 1.080 in 2007, this increase of $20 \%$ within a single year is substantial.

Our results are in line with the evidence of Grembi et al. (2014) who also establish a causal link of fiscal restraints for local government in Italy. Contrary to the Italian case studied by these authors, however, the reaction in our sample is not driven by the revenue side. We do not find any significant effects on the revenue side, but the effects on debt appear to be driven entirely by the expenditure side. ${ }^{1}$ Finally, we also analyze the interaction of some political economy aspects with the withdrawal of fiscal oversight. In particular, we find a significantly stronger debt increase in municipalities run by centerleft mayors, and we also find that municipalities that are relieved from oversight carried out by a center-left supervisor have significantly stronger increases in government debt.

Conceptually, fiscal restraints such as a balanced budget rule, have been justified from two different theoretical perspectives. First, as argued by Alesina and Perotti (1996), Persson and Svensson, Lars E. O. (1989), Tabellini and Alesina (1990), among others, the political decision-making process may generate an inherent deficit bias, and fiscal restraints which frame the political process, can potentially help to correct such bias. Moreover, within a federal system, governments may have strong incentives, or de iure

\footnotetext{
${ }^{1}$ Due to the switch of the accounting system, data on expenditures during our period of study are not directly comparable between municipalities and across periods. Thus, the adjustment on the expenditure side is only implied indirectly by the difference between the insignificant effects on revenue and the significant effect on debt.
} 
obligations, to provide funding to other, often lower level governments, if these are facing financial problems. Since these ex post incentives or explicit legal liabilities to provide assistance can be foreseen, they can generate ex ante incentives for excessive spending. Following Kornai (1986), the term "soft budget constraint" has been coined for this problem. It has been extensively studied by Epple and Spatt (1986), Qian and Roland (1998), Maskin (1999), Buettner and Wildasin (2006), Bordignon and Turati (2009), PetterssonLidbom (2010), and Baskaran (2012), among others, and is the second rationale for fiscal restraints (von Hagen (1991)).

In our analysis we cannot directly discriminate whether the effects of fiscal restraints on fiscal policy outcomes are driven by politico-economic imperfections or by soft budget considerations as we cannot observe bailout expectations. The latter would be necessary to properly identify the debt increase originating from soft budget constraint incentives, see Pettersson-Lidbom (2010). However, our finding that the random withdrawal of fiscal oversight only has an effect on previously restricted local governments may be considered evidence that, at least for the German municipalities under study, the politico-economic argument may be less important. Arguably, imperfections in the political process should affect all municipalities in a similar way, whereas the incentives of soft budget constraints are likely to be stronger for previously restricted municipalities with substantially higher average debt levels. However, it remains difficult to assess the soft budget constraint explanation even indirectly. While the state government of NRW is de facto liable for local government debt, grants to municipal governments have traditionally been rule-based and not discretionary, and explicit bailouts had not been observed before our period of study. However, since 2011, that is at least two years after the end of the accounting reform we focus on, the state government has engaged in several measures to increase grants available to local governments and has also established a discretionary program for individual municipalities to address the debt problem of the most indebted among them. ${ }^{2}$

The rest of the paper is structured as follows. Section 2 describes the institutional setting and our data set. Section 3 explains our identification strategy and the corresponding econometric framework. Section 4 presents the results and robustness checks, while Section 5 concludes the paper.

\footnotetext{
${ }^{2}$ The program is foreseen to last until 2021 and is currently still in its roll-out phase.
} 


\section{Institutional setting, data and descriptive statistics}

\subsection{Institutional setting}

With 17.5 million inhabitants in 2011 North Rhine-Westphalia (NRW) is the most populous state in Germany. It is divided into five administrative districts (Regierungsbezirke), Arnsberg, Detmold, Düsseldorf, Köln, and Münster, which consist of 31 counties (Kreise) and 23 urban districts (kreisfreie Städte). Due to several redivisions and amalgamations in the 1960s and 1970s there are 396 municipalities, which are relatively large and embrace approximately 45,000 inhabitants on average. The municipalities are classified into the 23 urban districts and 373 municipalities belonging to counties (kreisangehörige Städte und Gemeinden).

Municipalities have a constitutionally guaranteed right of self-government. However, their authority is limited by federal and state laws. A substantial part of local expenditures is employed for mandated duties with autonomy over the spending levels (e.g. expenditures for schools and kindergartens) or municipalities are obliged to solely execute responsibilities determined by federal or state law (e.g. some social expenditures). In areas such as general administration, cultural institutions, recreation and sport facilities, hospitals, local infrastructure, and public transport, municipalities have considerable discretion in their budgeting, see also Egger and Koethenbuerger (2010) and Baskaran (2014).

Local governments are financed through transfers by higher levels, e.g. state-allocated grants, and through tax revenues. Municipalities participate in a revenue sharing scheme which provides them with fixed shares of the local revenue from income taxation and VAT. However, local authorities have no discretion over the tax rates of these taxes. Municipalities are, within limits, free to set tax rate multipliers for three local taxes: a tax on business profits and two property taxes (on agricultural land and on business and private land). The mean ratio of own tax revenues (tax revenues without the local share in income taxes and VAT) to uncommitted municipal revenues (i.e. without earmarked funds) was $51 \%$ in 2011.

In general, local governments are not allowed to borrow. However, there are two exceptions to this rule. First, local governments are free to borrow to finance investment. We refer to this as "debt in the core budget" (Schulden im Kernhaushalt). ${ }^{3}$ Second,

\footnotetext{
${ }^{3}$ Since the 1990s there has been increased outsourcing of municipal responsibilities in particular in
} 


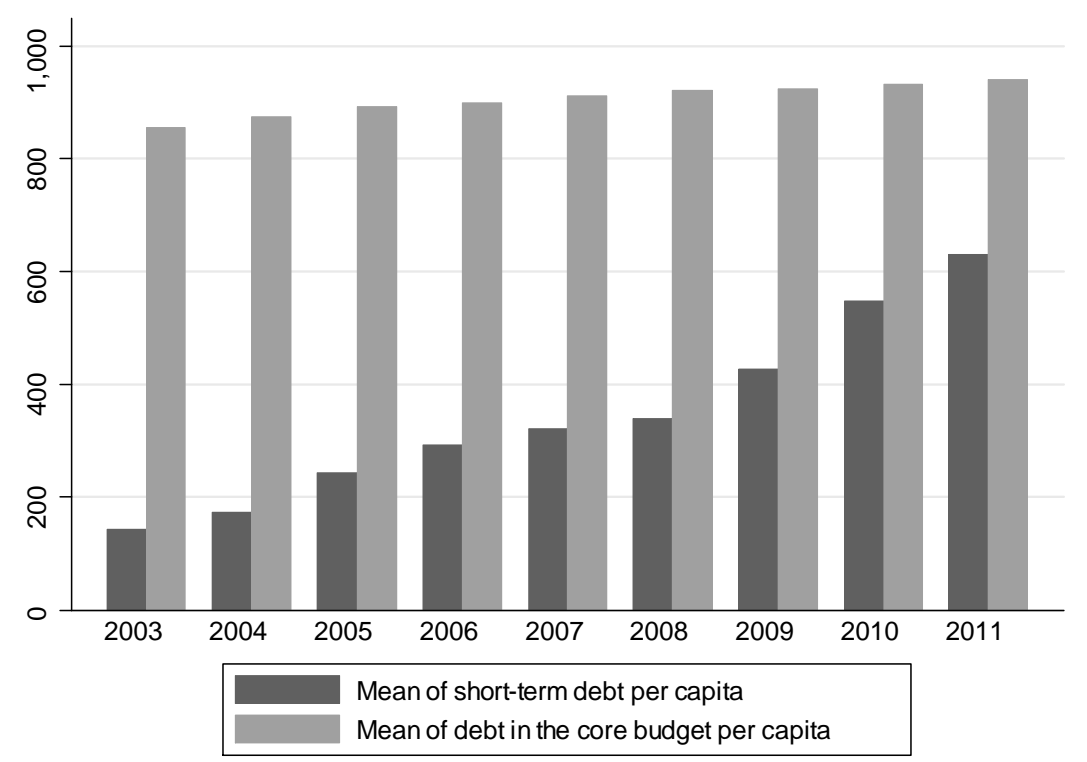

Figure 1: Level of short-term debt and debt in the core budget (2003-2011, municipalities NRW, EUR per capita, in prices of 2005)

the municipalities are allowed to assume short-term debt to ensure liquidity. In NRW especially the latter debt category has emerged dramatically over the time period under consideration from EUR 143 per capita in 2003 to EUR 630 per capita in 2011 (in prices of 2005) as shown in Figure 1. Heinemann et al. (2009) point out that the extent and persistence of short-term debt indicate that they are more and more used abusively to finance deficits. As they are less strictly regulated and not controlled directly by the local council, the distinction against debt in the core budget has been discussed extensively. ${ }^{4}$ Note that the switch to accrual accounting did not lead to a modification of the rules for these cash credits. We focus on short-term debt as our main variable of interest since this variable is an indicator to what extent local governments evade the constraint of the fiscal rule that forbids local government to engage in debt financing beyond capital investment.

In Germany, the state governments are legally required to guarantee local public services and those obligations that are mandated by federal or state law. Whether the states energy and water supply. Total local long-term debt (Schulden im Vermögenshaushalt) is therefore divided into the "debt in the core budget" (Schulden im Kernhaushalt) and the debt of local public firms. The latter kind of debt is less important for our analysis as it cannot be controlled by municipalities directly and on short notice, see also Fossen et al. (2014).

${ }^{4}$ The municipal council determines the maximum amount of short-term debt but the mayor takes the actual borrowing decision. 
are legally fully liable for existing local government debt is debated. However, the socalled principle of communality (Bündisches Prinzip) has been permanently upheld by the German courts with respect to fiscal obligations of the federal and state governments vis-à-vis each other, and this principle is generally seen as applying also to the relationship between state and local governments. Accordingly, it is commonly assumed that local government debt is backed by the respective state governments. In the history of the Federal Republic of Germany, there has not been a single case where a state government has ultimately not assumed the liabilities of a failing municipality. ${ }^{5}$

Despite chronic deficits in many municipalities, their creditors are generous with accommodating them with cash credits. Ade (2013) finds that creditors mostly ignore the financial situation when charging interest rates to local governments in Germany. This lack of credit constraints may be regarded as a direct consequence of the liability of the state governments. Alternatively, the benign financing conditions may be explained by access to credit from local public banks (Sparkassen), which are largely controlled either by individual municipalities or jointly by several municipalities. This finding is in contrast to federations with credible local government budget constraints and borrowing risk, see Capeci (1994), for instance, who studies the borrowing costs of municipalities in New Jersey.

Since 1991 a system of fiscal oversight of local government has been in place in NRW that requires each municipality to present its budget to a supervision authority as illustrated in Figure 2. The supervision is carried out at the county level, except for the urban districts, which are supervised by the administrative districts. The supervising authorities have substantial power. They are required to demand budget consolidation plans (Haushaltssicherungskonzepte) from all municipalities in financial distress, which are those municipalities that are unable to balance their budget. The consolidation plan must indicate how the municipality can again balance the budget within a period of four years. ${ }^{6}$ If the supervision authority decides that the consolidation plan is not sufficiently effective or credible, it disapproves the plan and the municipality is put under direct

\footnotetext{
${ }^{5}$ In NRW the non-existence of insolvency procedures for municipalities is regulated by the municipal code (§ 128 GemO NRW).

${ }^{6}$ In the cameralistic accounting system the budget consolidation plan would have been approved if it had been shown that revenues can cover expenditures (without deficits from previous years) within four years. With accrual accounting a balanced budget had to be achieved within three years following the financial year but, as discussed below in detail, a virtual buffer was granted to balance the budget until its depletion. Since 2011 this time period has been extended to ten years.
} 


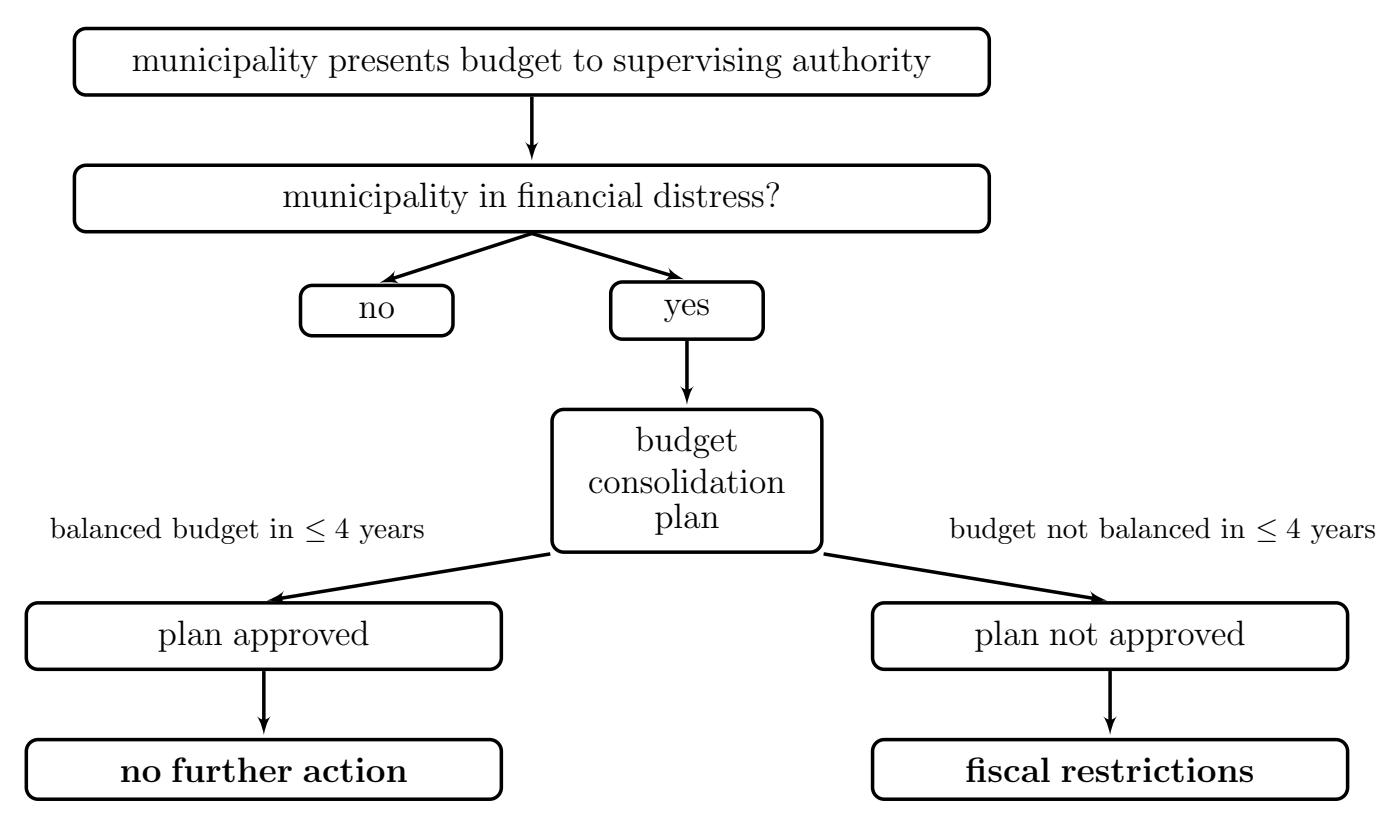

Figure 2: Fiscal oversight in NRW

fiscal supervision, i.e. its fiscal actions can be restricted by the supervision authority. Municipalities that are restricted in such a way are not allowed to reduce tax rates and need the approval of the supervision authority for all additional expenditures that are not mandated by state or federal legislation, and the authority can require further austerity measures. Even a complete take-over of the municipality's fiscal affairs is possible.

Our analysis exploits an institutional change that temporarily freed many municipalities from effective budget control to identify the effect of fiscal oversight on local government debt. In 1999, the Interior Ministers of the German states agreed to reform local government budget law in all states to replace traditional cash accounting by accrual accounting. The aim of this reform was to create more transparency in the financial situation of local government, and, in particular, to account for resource-consumption and the long-term financial consequences of policy decisions, see Ridder et al. (2005). NRW was the first state to enact these reforms by law in 2004 and implemented double-entry bookkeeping (accrual accounting) in municipal finance. All local governments had to introduce the new budgetary, control and reporting framework compulsory by 2009. As shown in Table 1 selected municipalities introduced the accrual accounting system in 2003 and 2005. These were mainly "model" municipalities for an evaluation procedure. Most municipalities switched to the new system after 2007. Figure 3 illustrates the regional switching pattern. 
Table 1: Implementation of accrual accounting in NRW

\begin{tabular}{ccc}
\hline \hline Year & Freq. & Percent \\
\hline 2003 & 1 & 0.25 \\
2005 & 8 & 2.02 \\
2006 & 33 & 8.33 \\
2007 & 83 & 20.96 \\
2008 & 132 & 33.33 \\
2009 & 139 & 35.10 \\
\hline Total & 396 & 100.00 \\
\hline
\end{tabular}

Apart from a shift from the traditional cameralistic accounting system on a cash-basis to a resource-based accrual accounting system with private sector accounting principles, the reform changed the conditions for the approval of local governments' budgets by the supervision authorities. In particular, the reform granted switching municipalities a one-time possibility to create an equalization reserve (Ausgleichsrücklage) in the opening balance. This reserve was intended to serve as a buffer to absorb accrued liabilities during the implementation period and to allow for fluctuations without direct interventions by the oversight authorities. Up to one third of the equity capital but no more than one third of the average revenues and general grants in the three years before adopting the reform could be designated to the equalization reserve. For nearly all municipalities the second criterion was the binding one. Except for a single case all municipalities chose the maximum reserve amount. ${ }^{7}$ Under the new accounting rules the requirement of a balanced budget could now be fulfilled in two ways without provoking action by the supervision authorities: either by actually balancing the budget, or, virtually, by covering the actual deficit by resorting to the equalization reserve. Note that the equalization reserve was purely notional and did not imply any additional transfer to the municipality. It was a pure accounting allowance that could be used by the municipalities when presenting their budget plans to the supervision authority to virtually balance their budget, even if the budget had to be balanced in practice by resorting to short-term debt. Thus, upon switching, the reserve could be used as a buffer by the switching municipalities. This provided most of the municipalities that were previously restricted by the supervising authorities an opportunity to act unrestrictedly, at least until the equalization reserve

\footnotetext{
${ }^{7}$ This municipality switched to accrual accounting in 2007 and is excluded from our estimations.
} 


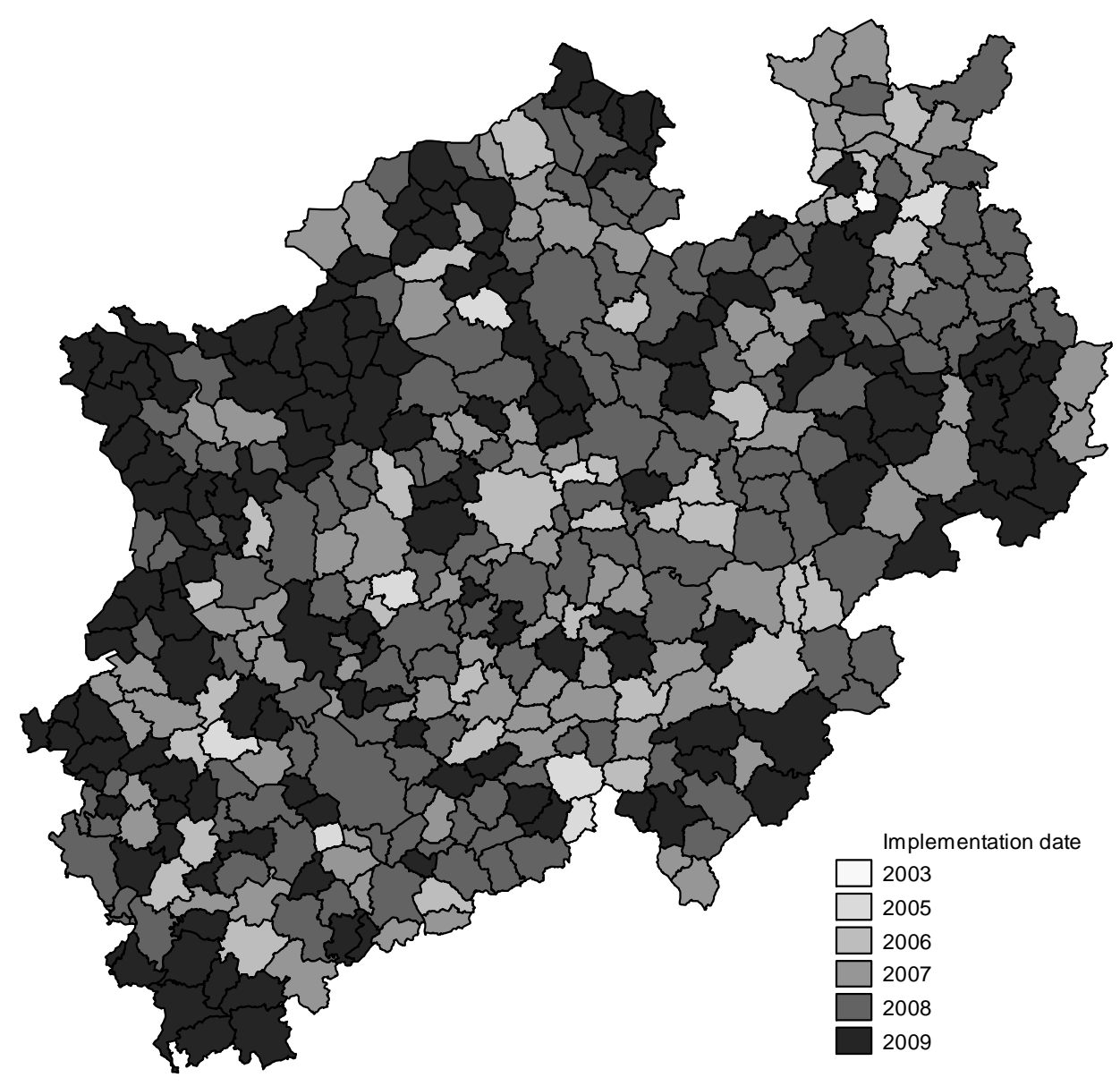

Figure 3: Implementation date, map NRW

was depleted. In some cases, the reserve was immediately depleted in the first year, such that these municipalities did not avoid effective oversight. However, more than two thirds of the municipalities which had to present a budget consolidation plan in the year before implementing the reform were not obligated to do so in the year after. This is also reflected in Figure 4 which shows the overall number of approved and disapproved budget consolidation plans in the period under study. The importance of supervision drops drastically in the years 2008 and 2009. The renewed increase in supervision after 2009 can be attributed to the effects of the financial crisis and the depletion of the equalization reserve by many municipalities. The reform allows us to analyze the effect of relaxing supervision on local borrowing and to compare the behavior of those municipalities with temporarily gained freedom from supervision to those municipalities that remained in the old system and did not benefit from the buffer. This comparison is particularly interesting for municipalities that were previously actively restricted by the supervision authorities. 


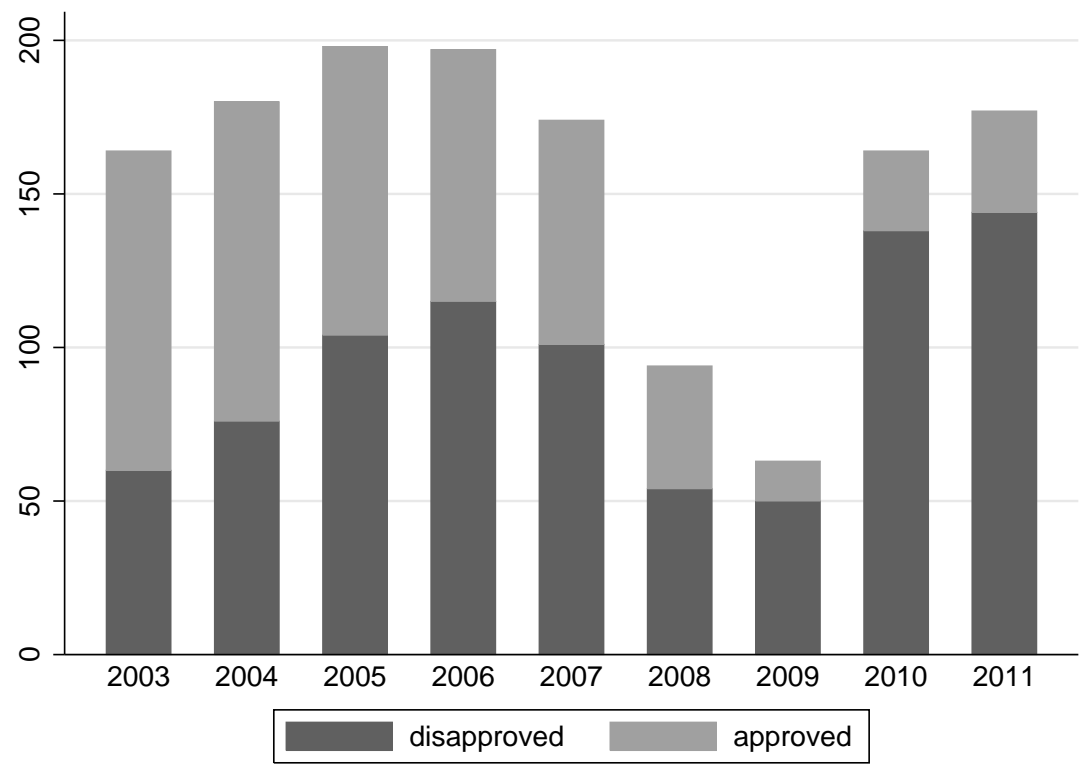

Figure 4: Approved and disapproved municipal budget consolidation plans (2003-2011)

\subsection{Data and descriptive statistics}

The basic balanced panel data set consists of all 396 municipalities in NRW, over nine years (2003-2011). To analyze the effects of fiscal oversight we mostly restrict our attention to the subsample of 271 municipalities which implemented accrual accounting in the years 2008 and 2009. Additionally, we also consider an enlarged panel that also contains the 89 municipalities which changed the accounting system in 2007 and the 33 municipalities that already switched in 2006.

We focus on short-term debt in the analysis as this part of debt is not backed by capital investment, shows substantial dynamics in the study period and represents a de facto breach of the fiscal rule in place, since local governments are legally not allowed to assume debt to balance their budgets. The data have been combined from different sources. Municipality-level financial data are obtained from the state's statistical office (Landesbetrieb Information und Technik Nordrhein-Westfalen), and have been deflated using the consumer price index for NRW. Additionally, we collected data on the change of the accounting system from the official opening balance sheets of the municipalities, especially on the effective date of the reorganization and on the size of the equalization reserve. Information on whether a municipality was obliged to present a budget consolidation plan, and, if so, whether it was approved, was extracted from publications of the 
Ministry of the Interior and completed by information from municipalities. Data on local election outcomes are obtained from the state's election supervisor (Landeswahlleiterin des Landes $N R W$ ). Table 2 provides descriptive statistics of our data set.

Table 2: Summary statistics (2003-2011)

\begin{tabular}{|c|c|c|c|c|c|}
\hline Variable & & Mean & Std. Dev. & Min. & Max. \\
\hline Population & Metric & $45,084.48$ & $87,436.99$ & 4,116 & $1,017,155$ \\
\hline Switch 2003 & Binary & 0.003 & 0.05 & 0 & 1 \\
\hline Switch 2005 & Binary & 0.02 & 0.14 & 0 & 1 \\
\hline Switch 2006 & Binary & 0.09 & 0.28 & 0 & 1 \\
\hline Switch 2007 & Binary & 0.21 & 0.41 & 0 & 1 \\
\hline Switch 2008 & Binary & 0.33 & 0.47 & 0 & 1 \\
\hline Switch 2009 & Binary & 0.35 & 0.48 & 0 & 1 \\
\hline Admin. Duesseldorf & Binary & 0.17 & 0.38 & 0 & 1 \\
\hline Admin. Koeln & Binary & 0.23 & 0.42 & 0 & 1 \\
\hline Admin. Muenster & Binary & 0.21 & 0.41 & 0 & 1 \\
\hline Admin. Detmold & Binary & 0.18 & 0.39 & 0 & 1 \\
\hline Admin. Arnsberg & Binary & 0.21 & 0.41 & 0 & 1 \\
\hline Urban district & Binary & 0.06 & 0.23 & 0 & 1 \\
\hline Equalization reserve, opening balance & EUR per capita & 409.33 & 103.17 & 0 & $1,036.65$ \\
\hline Consolidation plan presented & Binary & 0.37 & 0.48 & 0 & 1 \\
\hline Consolidation plan disapproved & Binary & 0.23 & 0.42 & 0 & 1 \\
\hline Debt in the core budget & EUR per capita & 900.96 & 632.89 & 0 & $5,271.97$ \\
\hline Short-term debt & EUR per capita & 342.89 & 676.41 & 0 & $7,571.07$ \\
\hline Tax multiplier property A & Metric & 223.99 & 38.49 & 145 & 402 \\
\hline Tax multiplier property B & Metric & 394.89 & 40.28 & 230 & 590 \\
\hline Tax multiplier business & Metric & 416.25 & 23.68 & 310 & 515 \\
\hline Fiscal capacity & EUR per capita & 824.18 & 301.32 & 334.47 & $2,773.67$ \\
\hline Total tax revenues & EUR per capita & 862.24 & 319.58 & 336.11 & $2,763.58$ \\
\hline Gross revenues $^{a}$ & EUR per capita & $1,679.11$ & 422.21 & 907.21 & $5,138.41$ \\
\hline Share council right-wing ${ }^{b}$ & Metric & 0.53 & 0.10 & 0.26 & 0.81 \\
\hline Share council left-wing ${ }^{b}$ & Metric & 0.36 & 0.10 & 0.05 & 0.66 \\
\hline Mayor right-wing $^{b}$ & Binary & 0.58 & 0.49 & 0 & 1 \\
\hline Mayor left-wing ${ }^{b}$ & Binary & 0.25 & 0.43 & 0 & 1 \\
\hline Supervisor right-wing $^{b}$ & Binary & 0.87 & 0.34 & 0 & 1 \\
\hline Divided government ${ }^{b}$ & Binary & 0.34 & 0.47 & 0 & 1 \\
\hline Alignment $^{b}$ & Binary & 0.58 & 0.49 & 0 & 1 \\
\hline
\end{tabular}

Notes: ${ }^{a}$ Data for years 2003-2008, ${ }^{b}$ Data from election period 2004-2009, right-wing comprises the center-right party CDU and the liberal party FDP, left-wing comprises the center-left party SPD and the Green Party (Bündnis 90/Die Grünen). Remaining mayors are independent candidates or from voter lists. Remaining seats in local councils are mainly held by local parties. The binary variable divided government takes the value 1 if mayor has no majority in the local council, the variable alignment takes the value 1 if mayor and supervisor have the same political orientation. 


\section{Econometric framework}

\subsection{Identification strategy}

Our identification strategy is based on the differences-in-differences method and exploits the fact that municipalities in North Rhine-Westphalia implemented the new system gradually. Switching made it temporarily more likely to effectively avoid fiscal oversight, and we are interested in how this affected the borrowing decisions of municipalities. As the municipalities could choose the year of the switch, this may challenge our identification. However, the timing may be considered exogenous for the behavior after the implementation for several reasons. First, the timing was largely determined by operational accounting considerations within the local administration. NRW was the fore-runner among the German states in the introduction of the new local government accounting system, such that the complex procedural requirements made the exact length of the necessary local preparation of the switch difficult to predict. Moreover, once the preparations enabling the switch were completed, postponing the switch implied substantial costs for the municipality. Second, there were no monetary incentives to strategically time the switch. The exact date of the switch only entered the determination of the virtual buffer, the equalization reserve, but did not affect the actual revenues of the municipalities in any way. The buffer allowance was largely determined by tax revenues in the three years preceding the switch, such that, even if a municipality had been aiming to maximize the equalization reserve, it would have been very challenging to predict the optimal switching date. Third, the decision to switch was taken by the municipal council (subject to the described operational implementation constraint), whereas the decisions regarding shortterm debt we focus on are taken by the mayor. Fourth, we mostly constrain our analysis to the subgroup of municipalities that either switched in 2008 or 2009. The two groups which implemented the new system in these years are very similar with respect to their trends in key fiscal variables in the years before 2008 as can be seen from Figures 5 and 6 which we discuss in detail below. Therefore, we first exclude all other municipalities from our analysis, and conduct the analysis with 262 municipalities which implemented the reform either in 2008 or $2009 .{ }^{8}$ In the year 2007 both groups still used the old accounting system whereas in 2008 one group was exposed to the treatment and the other was not.

\footnotetext{
${ }^{8}$ We also exclude eight municipalities which belong to the county of Aachen and the urban district of Aachen, since these were subject to substantial redivisions in 2009, which may have caused distortions in the preceding years. However, effects also hold when including these nine municipalities.
} 
Table 3: Determinants of the changeover year

\begin{tabular}{|c|c|c|c|c|c|}
\hline & $(1)$ & $(2)$ & $(3)$ & $(4)$ & $(5)$ \\
\hline debtshort 2007 & $\begin{array}{c}0.000171 \\
(1.19)\end{array}$ & $\begin{array}{c}0.000180 \\
(1.05)\end{array}$ & $\begin{array}{c}0.000154 \\
(1.06)\end{array}$ & $\begin{array}{c}0.0000995 \\
(0.63)\end{array}$ & $\begin{array}{c}0.0000570 \\
(0.31)\end{array}$ \\
\hline debtcore 2007 & $\begin{array}{c}0.000233^{*} \\
(1.77)\end{array}$ & $\begin{array}{c}0.000195 \\
(1.45)\end{array}$ & $\begin{array}{c}0.000264^{*} \\
(1.79)\end{array}$ & $\begin{array}{c}0.000244^{*} \\
(1.80)\end{array}$ & $\begin{array}{c}0.000245 \\
(1.55)\end{array}$ \\
\hline urban district & $\begin{array}{l}0.347 \\
(0.91)\end{array}$ & $\begin{array}{l}0.307 \\
(0.77)\end{array}$ & $\begin{array}{l}0.536 \\
(1.11)\end{array}$ & $\begin{array}{c}-0.0145 \\
(-0.03)\end{array}$ & $\begin{array}{l}0.199 \\
(0.33)\end{array}$ \\
\hline plan-present 2007 & & $\begin{array}{r}0.408^{*} \\
(1.91)\end{array}$ & & & $\begin{array}{l}0.386 \\
(1.56)\end{array}$ \\
\hline plan-disappr 2007 & & $\begin{array}{l}-0.376 \\
(-1.51)\end{array}$ & & & $\begin{array}{l}-0.246 \\
(-0.95)\end{array}$ \\
\hline revenues 2007 & & & $\begin{array}{c}0.000123 \\
(0.31)\end{array}$ & & $\begin{array}{c}0.00000959 \\
(0.02)\end{array}$ \\
\hline revenues 2006 & & & $\begin{array}{c}-0.000248 \\
(-0.52)\end{array}$ & & $\begin{array}{c}-0.000284 \\
(-0.57)\end{array}$ \\
\hline revenues 2005 & & & $\begin{array}{c}-0.0000677 \\
(-0.13)\end{array}$ & & $\begin{array}{c}0.00000244 \\
(0.00)\end{array}$ \\
\hline tax multiplier business 2007 & & & & $\begin{array}{c}0.0000891 \\
(0.01)\end{array}$ & $\begin{array}{c}-0.00169 \\
(-0.22)\end{array}$ \\
\hline tax multiplier prop A 2007 & & & & $\begin{array}{c}-0.00494^{*} \\
(-1.88)\end{array}$ & $\begin{array}{c}-0.00754^{* *} \\
(-2.40)\end{array}$ \\
\hline tax multiplier prop B 2007 & & & & $\begin{array}{c}0.00457 \\
(0.98)\end{array}$ & $\begin{array}{c}0.00697 \\
(1.43)\end{array}$ \\
\hline share council right-wing 2007 & & & & $\begin{array}{l}-0.518 \\
(-0.60)\end{array}$ & $\begin{array}{c}0.0559 \\
(0.06)\end{array}$ \\
\hline koeln & & & & & $\begin{array}{l}0.188 \\
(0.68)\end{array}$ \\
\hline muenster & & & & & $\begin{array}{c}-0.0122 \\
(-0.05)\end{array}$ \\
\hline detmold & & & & & $\begin{array}{c}0.604^{* *} \\
(2.06)\end{array}$ \\
\hline arnsberg & & & & & $\begin{array}{c}0.622^{* *} \\
(2.17)\end{array}$ \\
\hline _cons & $\begin{array}{c}-0.324^{* *} \\
(-2.40)\end{array}$ & $\begin{array}{c}-0.386^{* * *} \\
(-2.71)\end{array}$ & $\begin{array}{c}-0.0677 \\
(-0.16) \\
\end{array}$ & $\begin{array}{l}-0.755 \\
(-0.35) \\
\end{array}$ & $\begin{array}{l}-0.626 \\
(-0.24)\end{array}$ \\
\hline $\begin{array}{l}N \\
\text { pseudo } R^{2}\end{array}$ & $\begin{array}{c}262 \\
0.029\end{array}$ & $\begin{array}{c}262 \\
0.040\end{array}$ & $\begin{array}{c}262 \\
0.030\end{array}$ & $\begin{array}{c}262 \\
0.046\end{array}$ & $\begin{array}{c}262 \\
0.089\end{array}$ \\
\hline
\end{tabular}

Notes: Regression coefficients of probit models. 262 municipalities included which switched either in 2008 or 2009. The dependent variable is implementation of accrual accounting in 2008. T statistics are in parentheses. Omitted variable in (5): administrative district Duesseldorf. ${ }^{*} p<0.10,{ }^{* *} p<0.05,{ }^{* * *} p<0.01$

One potential motive for switching could be the size of the equalization reserve as the relaxation of supervision was contingent on the size of this reserve. It could amount up to one third of the equity capital but not more than one third of the mean revenues and general grants in the three years before adopting the reform. For more than 95 per cent in our sample the second criterion was the binding one. Therefore, we can observe whether the choice in 2007 to introduce accrual accounting in the following year or to wait one more year was affected by the size of the equalization reserve. We include revenues of the three preceding years in binary probit regression models and do not find systematic correlations. The results are presented in Table 3. Furthermore, this analysis also shows 

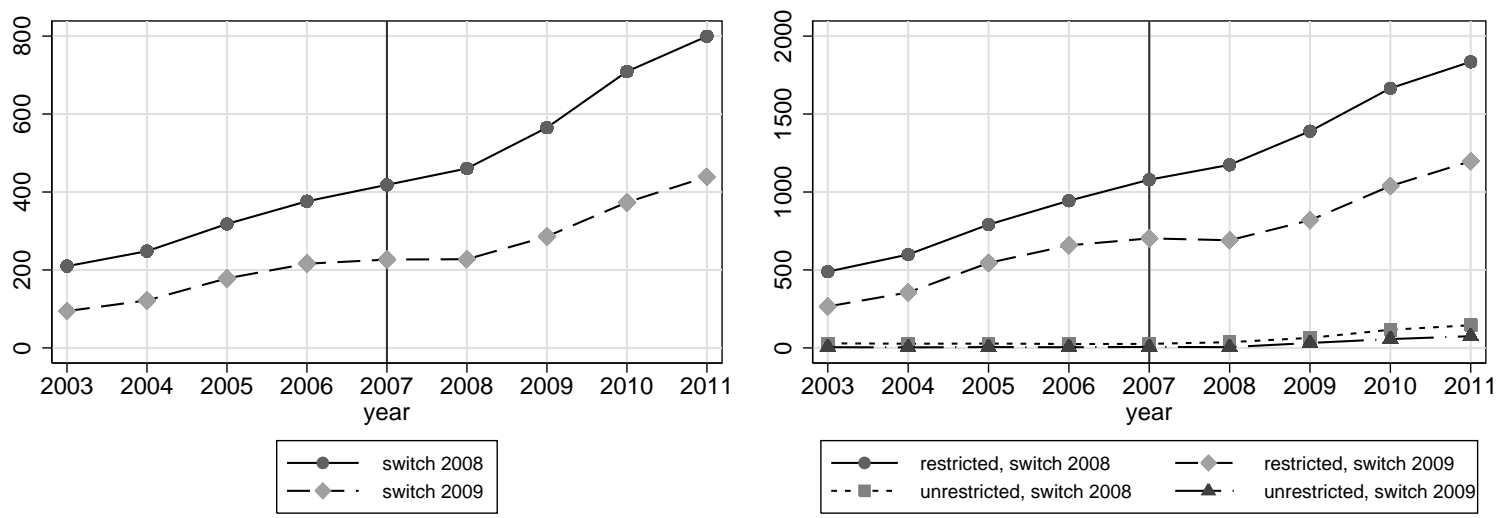

Figure 5: Short-term debt 2003-2011 (EUR per capita, in prices of 2005). The left panel shows all municipalities which switched in 2008 or 2009, the right panel uses only the restricted and unrestricted municipalities which switched in 2008 or 2009.

that neither a municipality's debt level nor being under fiscal supervision played a role for the switching date. The political majorities in the council also did not affect the switching year. We also control for other characteristics and find only a minor regional pattern and a small effect for the property tax multiplier on agricultural land. The latter tax, however, raises very little revenue (on average EUR 4.53 per capita) and is mostly irrelevant for local budgets. In summary, these findings demonstrate that the switching year is uncorrelated with any key fiscal and political variables before the treatment. Thus, the assignment to the treatment group, i.e. those municipalities switching in 2008, can be considered to be sufficiently exogenous.

Relaxing fiscal oversight could have different effects for municipalities which were subject to binding fiscal oversight before the reform and those municipalities where the supervision authorities did not intervene. We therefore establish two important subgroups in our sample, the "restricted" and the "unrestricted" group. The restricted subgroup had to provide a budget consolidation plan in 2007 which was disapproved subsequently, whereas the unrestricted group did not have to present a plan in 2007. Note that these two groups together do not include all municipalities, since there was also a substantial number of municipalities that had to present a consolidation plan which was approved.

To assess the common trends assumption for the municipalities which implemented the reform in 2008 and those which switched in 2009 we plot the development of the level of short-term debt in Figure 5. The graph on the left-hand side illustrates that there are no significant systematic differences in the trend before 2008 between those municipalities 

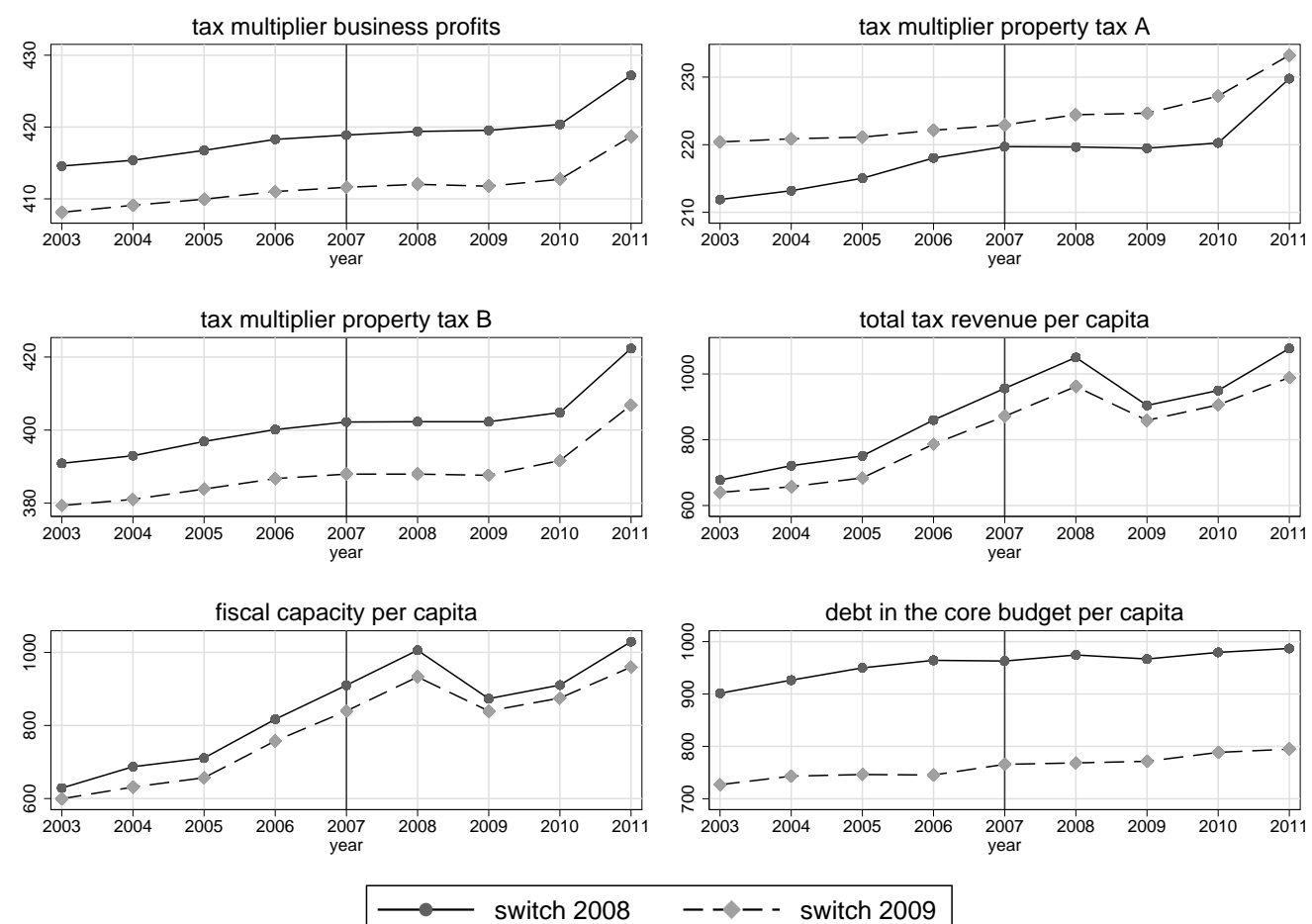

$--\bullet-$ switch 2009

Figure 6: Tax rate multipliers, total tax revenues per capita, fiscal capacity per capita, and debt in the core budget (2003-2011)

that switched in 2008 and those that switched in 2009. Thus, the key common trends assumption appears to be valid for the two groups. ${ }^{9}$ Moreover, the graphs already hint at the different behavior of short-term debt in the two groups after the treatment. The panel on the right-hand side of Figure 5 also plots short-term debt per capita but does so separately for the subgroups of restricted and unrestricted municipalities switching in 2008 and 2009, respectively. The displayed pattern suggests that the common trends assumption also holds for these subgroups. Moreover, it indicates that the treatment does not appear to have any effect on the unrestricted municipalities. These municipalities hardly incur any short-term debt before and after the treatment, at least until the onset of the financial crisis. This indicates that a more detailed analysis of these subgroups is warranted.

In Figure 6 we additionally plot the development of the three tax multipliers, total tax revenue, fiscal capacity, and debt in the core budget per capita. The municipalities

\footnotetext{
${ }^{9}$ This is also corroborated by the results of placebo treatments for earlier years as shown in Table 6 , and discussed in our robustness checks.
} 
are, within limits, free to set multipliers which are then applied to the respective tax bases. Whilst the tax on business profits (mean revenues 2007: EUR 431.45 per capita) and the tax on private and business land (mean revenues 2007: EUR 118.78 per capita) represent the main sources of self-controlled revenues, the tax on agricultural land (multiplier on property tax A) is less important (mean revenues 2007: EUR 4.73 per capita). Municipalities receive grants through the fiscal equalization scheme based on their fiscal capacity. ${ }^{10}$ Apart from the tax multiplier A, which is mostly irrelevant for municipal finances, all these variables which characterize the main revenue sources of the municipalities show clear pre-treatment common trends. During the treatment period we cannot observe trend differences in the variables. This underlines that, in general, treated and non-treated municipalities behave very similar over time. Moreover, the graphs indicate that potential changes on the revenue side coinciding with the treatment cannot explain our findings with respect to the effects on short-term debt.

\subsection{Empirical model}

The dependent variable is the per capita level of short-term debt $\left(d e b t_{i t}\right)$. Moreover, given the panel structure of our data we employ a fixed effects approach with municipalityspecific intercepts and a set of time effects to control for unobserved heterogeneity between municipalities and time trends. We estimate models of the following form for municipality $i$ in year $t$

$$
\text { debt }_{i t}=\alpha_{i}+\beta_{1} \text { treat }_{i t}+\beta_{2} \text { treat }_{i t} * \text { restr }_{i t-1}+\sum_{k} \beta_{k} X_{k i t}+\gamma_{t}+e_{i t}
$$

where $\alpha_{i}$ are municipality fixed effects, treat $t_{i t}$ is a dummy variable indicating whether a municipality has implemented the reform in year $t$, rest $_{i t-1}$ is a dummy variable indicating whether a municipality is directly constrained by the supervision authority, i.e. that its budget consolidation plan had been disapproved in the year preceding the switch, $\beta_{1}$ and $\beta_{2}$ are our parameters of interest, $\gamma_{t}$ are year dummies, and $X_{k i t}$ are additional explanatory variables with parameters $\beta_{k}$. We estimate (1) for the sample of municipalities that switched in 2008 or 2009 as well as for a more general panel that includes all municipalities that switched between 2006 and 2009. Additionally, we directly estimate separate regressions of (1), without the interaction, for specific subgroups, because relaxing supervision should have different effects for formerly more or less restricted municipalities.

\footnotetext{
${ }^{10}$ The fiscal capacity of a municipality is determined by the tax bases of the local taxes and its fixed shares from the VAT and income tax revenues.
} 


\section{Results}

\subsection{Main results}

We first present the results from estimating the effect of the switch on short-term debt for the panel of those 262 municipalities which adopted the reform in 2008 or 2009. The municipalities which implemented accrual accounting in 2008 are referred to as "switching municipalities". Column (1) in Table 4 shows the results for a simple specification without municipality fixed effects and with time fixed effects. Columns (2) and (3) report the results with municipality fixed effects (2), and, additionally, with further controls (3). We include two dummy variables indicating whether a municipality had to present a budget consolidation plan (plan-present) and whether a municipality had been put under active fiscal supervision (plan-disappr) in the current year. With municipality and time fixed effects the estimated effect on cash credit per capita for the switching municipalities is an increase by EUR 86.20 per capita compared to the municipalities which had not yet implemented the reform. The estimated effect is statistically significantly different from zero at the 0.05 level. When including further controls, the average treatment effect is EUR 105.80 per capita. The mean of short-term debt of the switching municipalities was EUR 418.35 in 2007 implying that this increase was quantitatively important.

In a next step we consider two important subgroups to study the potentially different effects of relaxing supervision on municipalities that were actually restricted by the oversight authorities, and those municipalities where the oversight authorities typically approved the budget without requirements or actual intervention. To this end, we consider the 73 "restricted" municipalities which had to present a budget consolidation plan in the year before the reform was implemented, and where the plan had been disapproved by the supervising authorities. As expected, effects for this group are very large. Even when considering the higher mean cash credits of this group (EUR 1,078.83 for switching and restricted municipalities in 2007) the estimated effect of EUR 208.80 which is statistically significantly different from zero at the 0.05 level is substantial. When including the two dummy variables on the presentation and disapproval of the consolidation plan, the estimated effect is even higher (EUR 285.50) and also statistically significantly different from zero at the 0.05 level. Additionally, we restrict our sample to those 135 municipalities which had not been restricted by budgetary supervision and did not present a budget consolidation plan in 2007 ("unrestricted"). For these municipalities there are no effects 


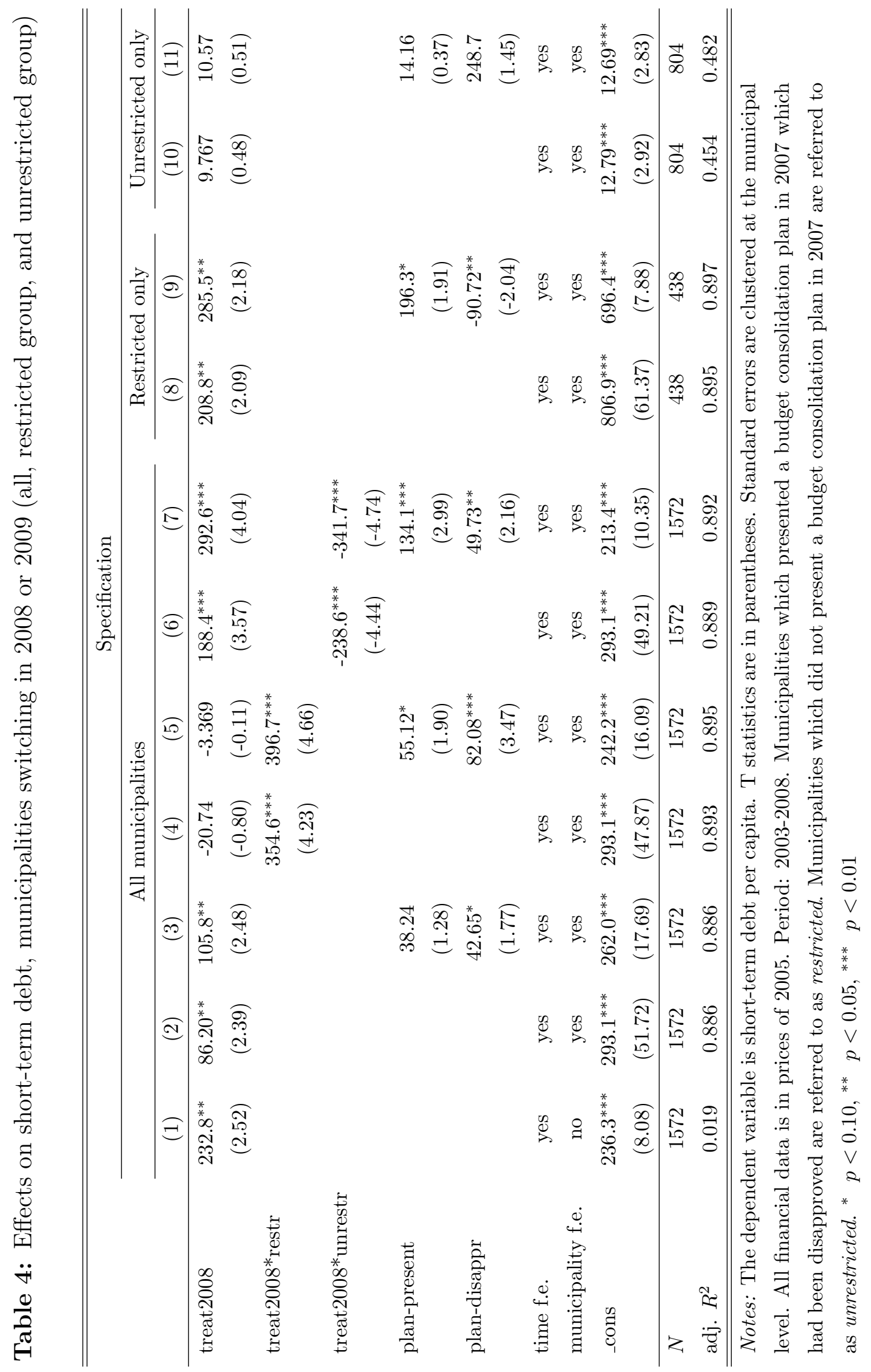


from the withdrawal of oversight, see Column (10) and (11) in Table 4. The estimates illustrate that the withdrawal of supervision only has an effect on those municipalities that are actively constrained by fiscal oversight. This is in line with graphical evidence from Figure 5, which illustrates the difference between the restricted and the unrestricted groups.

We also estimate the model for the whole panel to check whether the effect remains when including municipalities which introduced accrual accounting in 2006 or 2007. The nature of our results presented in Table 5 remains unchanged also for this enlarged panel. In the year before the switch $($ switch $*(t-1))$ there is no significant effect on debt. After the switch there is an increase of short-term debt per capita which remains pronounced also in the second year after the switch.

Table 5: Effects on short-term debt per capita, municipalities which switched in 2006, 2007, 2008 or 2009

\begin{tabular}{lcc}
\hline \hline & $(1)$ & $(2)$ \\
\hline switch*(t-1) & 22.74 & 23.39 \\
& $(1.53)$ & $(1.61)$ \\
switch*t & $52.83^{*}$ & -11.05 \\
& $(1.90)$ & $(-0.41)$ \\
switch*(t+1) & $105.8^{* *}$ & $102.1^{* *}$ \\
& $(2.30)$ & $(2.35)$ \\
switch*restr & & $258.6^{* * *}$ \\
& & $(6.75)$ \\
plan-present & 15.54 & 24.93 \\
& $(0.73)$ & $(1.17)$ \\
plan-disappr & $47.85^{* *}$ & $76.18^{* * *}$ \\
& $(2.04)$ & $(3.33)$ \\
time f.e. & yes & yes \\
municipality f.e. & yes & yes \\
_cons & $128.0^{* * *}$ & $119.0^{* * *}$ \\
& $(6.72)$ & $(6.27)$ \\
\hline$N$ & 2621 & 2621 \\
adj. $R^{2}$ & 0.864 & 0.869 \\
\hline \hline
\end{tabular}

Notes: The dependent variable is short-term debt per capita. T statistics are in parentheses. All financial data is in prices of 2005. Standard errors are clustered at the municipal level. Period: 2003-2011. Municipalities which presented a disapproved budget consolidation plan in the year before introducing accrual accounting are referred to as restricted. ${ }^{*} p<0.10,{ }^{* *} p<0.05,{ }^{* * *} p<0.01$. 


\subsection{Robustness checks}

To analyze whether the treatment and the control group already differed before introducing the accrual accounting system we construct placebo treatments. As depicted in Table 6 we cannot observe an effect in earlier years supporting the common trends assumption. The interaction effects are statistically insignificant for earlier years indicating that time trends of both groups were similar before the treatment. However, in the years after the switch of the accounting system there remains a pronounced effect which may also be due to the fact that municipalities which introduced accrual accounting in 2008 experienced a longer term of relaxed supervision on average, because of the onset of the financial crisis. Because of the crisis most municipalities which had been restricted in 2007, and before, were put under fiscal supervision again in 2010. Moreover, the lasting differences between the two groups may also be due to the persistence of costs connected with expenditures made in the periods without supervision. Finally, the relaxation of oversight continued for all municipalities which did not deplete their equalization reserve, since the remaining reserve could be used in subsequent years to fictitiously balance the budget. Potentially, these municipalities became increasingly aware of this possibility over time, such that they abused this possibility even to a larger extent in the years following the switch.

Our results are also qualitatively robust to the exclusion of eight municipalities which elected a mayor between 2004 and 2009, and to the exclusion of municipalities in four counties where local elections of county administrators took place during this period. If we exclude those heavily indebted municipalities which did not escape direct fiscal oversight despite of the buffer allowance, because they immediately depleted their equalization reserve in the first year, the average treatment effects are smaller in absolute numbers, given the lower mean level of short-term debt for the remaining group. However, in relative terms the effect is larger. We find an increase of $30 \%$ for those switching municipalities which were previously restricted and actually escaped supervision. Main results of these robustness tests can be found in Table A1 in the Appendix. ${ }^{11}$

Finally, in a further test we check whether the definition of a restricted municipality drives our results. For various alternative definitions of "restricted" Table 7 shows that the effect is very robust and is even stronger when only considering municipalities which were restricted for a longer time period, as is evident from Column 6 of Table 7. This

\footnotetext{
${ }^{11}$ Of course, whether a municipality depletes its equalization reserve already in the switching year, and therefore is never subject to the withdrawal of oversight, is endogenously determined by the municipality.
} 
Table 6: Placebo treatments

\begin{tabular}{lccc}
\hline \hline & All municipalities & Restricted only & \multicolumn{2}{c}{ Unrestricted only } \\
& $(1)$ & $(2)$ & 9.161 \\
& $136.1^{* *}$ & $374.2^{* *}$ & $(0.30)$ \\
treat2008 & $(2.18)$ & $(2.35)$ & 50.12 \\
treat2008*2011 & $244.7^{* *}$ & 369.8 & $(1.12)$ \\
treat2008*2010 & $(2.51)$ & $358.3^{*}$ & 38.56 \\
& $218.4^{* *}$ & $(1.67)$ & $(0.93)$ \\
treat2008*2009 & $(2.51)$ & $286.9^{*}$ & 9.543 \\
& $168.1^{* *}$ & $(1.68)$ & $(0.31)$ \\
treat2008*2007 & $(2.34)$ & 109.5 & -3.414 \\
& 73.37 & $(0.89)$ & $(-0.18)$ \\
treat2008*2006 & $(1.53)$ & 10.70 & -3.078 \\
treat2008*2005 & 45.28 & $(0.11)$ & $(-0.28)$ \\
treat2008*2004 & $(1.24)$ & -22.45 & -0.982 \\
plan-present & 22.80 & $(-0.32)$ & $(-0.07)$ \\
& $(0.93)$ & 41.54 & -0.121 \\
plan-disappr & 6.679 & $(0.81)$ & $(-0.01)$ \\
& $(0.43)$ & $361.6^{* * *}$ & 24.02 \\
time f.e. & 34.78 & $(3.71)$ & $(0.31)$ \\
municipality f.e. & $(1.15)$ & $-179.4^{* * *}$ & 42.07 \\
-cons & $66.96^{* *}$ & $(-2.73)$ & $(0.45)$ \\
& $(2.05)$ & yes & yes \\
adj. $R^{2}$ & yes & yes & yes \\
\hline \hline
\end{tabular}

Notes: The dependent variable is short-term debt per capita. T statistics are in parentheses. All financial data is in prices of 2005. Period: 2003-2011. Standard errors are clustered at the municipal level. Municipalities which presented a budget consolidation plan in 2007 which had been disapproved are referred to as restricted. Municipalities which did not present a budget consolidation plan in 2007 are referred to as unrestricted. Omitted variable: treat2008*2003. ${ }^{*} p<0.10,{ }^{* *} p<0.05,{ }^{* * *} p<0.01$

corroborates the notion that relaxing oversight is particularly important for municipalities which have been restricted for a long time.

\subsection{Political economy aspects}

Using our identification strategy we can also test various political economy theories of public deficits. In the institutional setting in NRW, mayors, the members of local councils, and also county heads, who are in charge of the supervision authority at the county level, are elected and typically affiliated with political parties. Accordingly, we can investigate whether the party affiliation of these policy actors (mayors, council majorities, and county heads or district administrators), or certain political constellations affect the behavior of municipalities after the withdrawal of oversight. Constellations of interest are, in particular, the potential party alignment of the local mayor and the responsible supervisor, or the effects of a divided government at the local level, i.e. where the mayor has a different 
Table 7: Effects on short-term debt per capita, different measures for "restricted"

\begin{tabular}{|c|c|c|c|c|c|c|}
\hline & \multicolumn{6}{|c|}{ Specification } \\
\hline & \multicolumn{2}{|c|}{ A } & \multicolumn{2}{|c|}{ B } & \multicolumn{2}{|c|}{$\mathrm{C}$} \\
\hline & (1) & $(2)$ & (3) & (4) & (5) & (6) \\
\hline \multirow[t]{2}{*}{ treat2008 } & $-44.43^{*}$ & $180.1^{* *}$ & 17.50 & $231.4^{*}$ & -6.056 & $459.0^{* * *}$ \\
\hline & $(-1.69)$ & $(1.99)$ & $(0.47)$ & $(1.70)$ & $(-0.21)$ & $(3.72)$ \\
\hline \multirow[t]{2}{*}{ treat2008*restr $(\mathrm{A})$} & $343.5^{* * *}$ & & & & & \\
\hline & $(4.71)$ & & & & & \\
\hline \multirow[t]{2}{*}{ treat2008*restr $(\mathrm{B})$} & & & $414.3^{* * *}$ & & & \\
\hline & & & $(4.66)$ & & & \\
\hline \multirow[t]{2}{*}{ treat2008*restr $(\mathrm{C})$} & & & & & $325.0^{* * *}$ & \\
\hline & & & & & $(4.39)$ & \\
\hline controls & yes & yes & yes & yes & yes & yes \\
\hline time f.e. & yes & yes & yes & yes & yes & yes \\
\hline municipality f.e. & yes & yes & yes & yes & yes & yes \\
\hline \multirow[t]{2}{*}{ _cons } & $213.0^{* * *}$ & $488.5^{* * *}$ & $249.5^{* * *}$ & $846.2^{* * *}$ & $222.9^{* * *}$ & 162.5 \\
\hline & $(10.32)$ & $(7.92)$ & $(17.56)$ & $(9.54)$ & $(12.21)$ & $(1.39)$ \\
\hline$N$ & 1572 & 732 & 1572 & 330 & 1572 & 606 \\
\hline adj. $R^{2}$ & 0.892 & 0.887 & 0.894 & 0.915 & 0.892 & 0.897 \\
\hline
\end{tabular}

Notes: The dependent variable is short-term debt per capita. T statistics are in parentheses. All financial data is in prices of 2005. Standard errors are clustered at the municipal level. Period: 2003-2008. Specifications: A

$=$ consolidation plans presented 2005-2007, B = consolidation plans not approved 2005-2007, C = consolidation plans presented 2003-2007. (2), (4), (6): restricted subgroup separately. ${ }^{*} p<0.10,{ }^{* *} p<0.05,{ }^{* * *} p<0.01$

political orientation than the majority of members in the local council.

Local elections usually take place simultaneously throughout the state, and such regular local elections took place in 2004 and 2009. In a few cases, bi-elections were necessary to elect a new mayor or a new head of county. Except for these few cases, which we exclude from our analysis, the local political constellation given by the majority in the council and the mayor, as well as the party affiliation of the head of county and the district administrator were constant over the period when fiscal oversight was relaxed as a consequence of the accounting reform. In our analysis, we restrict our sample to the years between the two elections (2004-2008), but results using the full panel are actually similar.

We classify mayors, county heads, district administrators and council majority by political orientation. Individuals affiliated with the center-left party SPD and the Green Party (Bündnis 90/Die Grünen) are considered left-wing, whereas individuals affiliated with the center-right party CDU and the liberal party FDP are considered as right-wing. Beyond these two groups there are politicians that belong to smaller local parties or run as independent candidates. We find that the increase of short-term debt in response to the absence of fiscal oversight is significantly higher for left-wing mayors and this 
appears to be driving the overall effect of the withdrawal of fiscal oversight. As regards the supervision authorities, the increase in short-term debt in response to the withdrawal of oversight is significantly stronger for those municipalities that are supervised by an authority run by a head who is affiliated with a left-wing party. This is in line with the findings of Roesel (2014). For divided government we find no significant effects, and also no evidence regarding an alignment effect between the mayor and the head of the supervision authority. The fact that the mayor and the supervisor share the same political orientation does not affect the behavior after the withdrawal of oversight. Table A2 in the Appendix summarizes our main findings for these political variables, and these findings are typically robust if we only consider the subgroup of restricted municipalities as discussed above.

\section{Discussion and conclusion}

Our analysis provides strong evidence for causal effects of fiscal rules on fiscal policy outcomes. The withdrawal of fiscal oversight results in a substantial increase of local government debt for municipalities which were previously constrained by the supervision authorities. This proves the importance of fiscal restraints on local government debt.

Our results also highlight the importance of fiscal oversight and enforcement of fiscal restraints. In a system characterized by fiscal rules and decentralized policy-making but without oversight and enforcement, fiscal restraints are not strictly binding and their effectiveness as a constraint on debt is substantially reduced. Strong oversight is therefore necessary to achieve a binding constraint on debt. However, to the extent that the problem stems from the existence of soft budget constraints, hardening soft budget constraints by credible no bailout provisions and sound bankruptcy procedures for local government may also address the deficit challenge. If this is not an option, or if policy-making suffers from a politico-economic deficit bias, strengthening fiscal oversight and enforcement is important for the functioning of fiscal rules.

Finally, Grembi et al. (2014) show that fiscal restraints are actually effective in an environment where institutional quality is relatively weak and they argue accordingly that even countries suffering from weak governance can potentially reduce local government debt by introducing fiscal restraints. Given the German reputation for abiding rules and the relatively high institutional quality in Germany, as measured by typical governance quality indicators, see Kaufmann et al. (2010), our results can be seen as providing an 
important complementary finding. Fiscal restraints also matter in countries with relatively well-functioning institutions, but even in such a context, oversight and enforcement remain important for their effectiveness.

\section{References}

Ade, F. (2013). Do Creditors Discipline Local Governments? In Local Public Choice: Five Essays on Fiscal Policy, Interest Rates, and Elections. Baden-Baden: Nomos.

Alesina, A. and R. Perotti (1996). Fiscal Discipline and the Budget Process. American Economic Review, Papers and Proceedings 86(2), 401-407.

Baskaran, T. (2012). Soft Budget Constraints and Strategic Interactions in Subnational Borrowing: Evidence from the German States, 1975-2005. Journal of Urban Economics 71(1), $114-127$.

Baskaran, T. (2014). Identifying Local Tax Mimicking with Administrative Borders and a Policy Reform. Journal of Public Economics 118, 41-51.

Besley, T. and M. Smart (2007). Fiscal Restraints and Voter Welfare. Journal of Public Economics 91(3-4), 755-773.

Bordignon, M. and G. Turati (2009). Bailing Out Expectations and Public Health Expenditure. Journal of Health Economics 28(2), 305-321.

Brennan, G. and J. M. Buchanan (1980). The Power to Tax: Analytical Foundations of a Fiscal Constitution. Cambridge: Cambridge University Press.

Buettner, T. and D. E. Wildasin (2006). The Dynamics of Municipal Fiscal Adjustment. Journal of Public Economics 90(6-7), 1115-1132.

Capeci, J. (1994). Local Fiscal Policies, Default Risk, and Municipal Borrowing Costs. Journal of Public Economics 53(1), 73-89.

Drazen, A. (2004). Fiscal Rules from a Political Economy Perspective. In G. F. Kopits (Ed.), Rules-Based Fiscal Policy in Emerging Markets: Background, Analysis and Prospects. New York: Palgrave Macmillan.

Egger, P. and M. Koethenbuerger (2010). Government Spending and Legislative Organization: Quasi-Experimental Evidence from Germany. American Economic Journal: Applied Economics 2(4), 200-212.

Epple, D. and C. Spatt (1986). State Restrictions on Local Debt: Their Role in Preventing Default. Journal of Public Economics 29(2), 199-221.

Fossen, F. M., R. Freier, and T. Martin (2014). Race to the Debt Trap? Spatial Econometric Evidence on Debt in German Municipalities. DIW Discussion Paper No. 1358. 
Grembi, V., T. Nannicini, and U. Troiano (2014). Policy Responses to Fiscal Restraints: A Difference-in-Discontinuities Design. Harvard Economics Department Working Paper.

Halac, M. and P. Yared (2014). Fiscal Rules and Discretion under Persistent Shocks. Econometrica 82(5), 1557-1614.

Heinemann, F., L. P. Feld, B. Geys, C. Gröpl, S. Hauptmeier, and A. Kalb (2009). Der kommunale Kassenkredit zwischen Liquiditätssicherung und Missbrauchsgefahr. ZEWWirtschaftsanalysen. Baden-Baden: Nomos.

Kaufmann, D., A. Kraay, and M. Mastruzzi (2010). The Worldwide Governance Indicators: Methodology and Analytical Issues. World Bank Policy Research Working Paper No. 5430 .

Kornai, J. (1986). The Soft Budget Constraint. Kyklos 39(1), 3-30.

Maskin, E. S. (1999). Recent Theoretical Work on the Soft Budget Constraint. The American Economic Review 89(2), 421-425.

Persson, T. and Svensson, Lars E. O. (1989). Why a Stubborn Conservative Would Run a Deficit: Policy with Time-Inconsistent Preferences. The Quarterly Journal of Economics 104 (2), 325-345.

Pettersson-Lidbom, P. (2010). Dynamic Commitment and the Soft Budget Constraint: An Empirical Test. American Economic Journal: Economic Policy 2(3), 154-179.

Poterba, J. M. (1996). Budget Institutions and Fiscal Policy in the U.S. States. The American Economic Review 86(2), 395-400.

Qian, Y. and G. Roland (1998). Federalism and the Soft Budget Constraint. The American Economic Review 88(5), 1143-1162.

Ridder, H.-G., H.-J. Bruns, and F. Spier (2005). Analysis of Public Management Change Processes: The Case of Local Government Accounting Reforms in Germany. Public Administration 83(2), 443-471.

Roesel, F. (2014). Co-Partisan Buddies or Partisan Bullies? Why State Supervision of Local Government Borrowing Fails. Ifo Working Paper No. 189.

Tabellini, G. and A. Alesina (1990). Voting on the Budget Deficit. The American Economic Review 80(1), 37-49.

von Hagen, J. (1991). A Note on the Empirical Effectiveness of Formal Fiscal Restraints. Journal of Public Economics 44(2), 199-210.

Wyplosz, C. (2012). Fiscal Rules: Theoretical Issues and Historical Experiences. In Fiscal Policy after the Financial Crisis, NBER Chapters.

\section{A Appendix: Additional Tables}




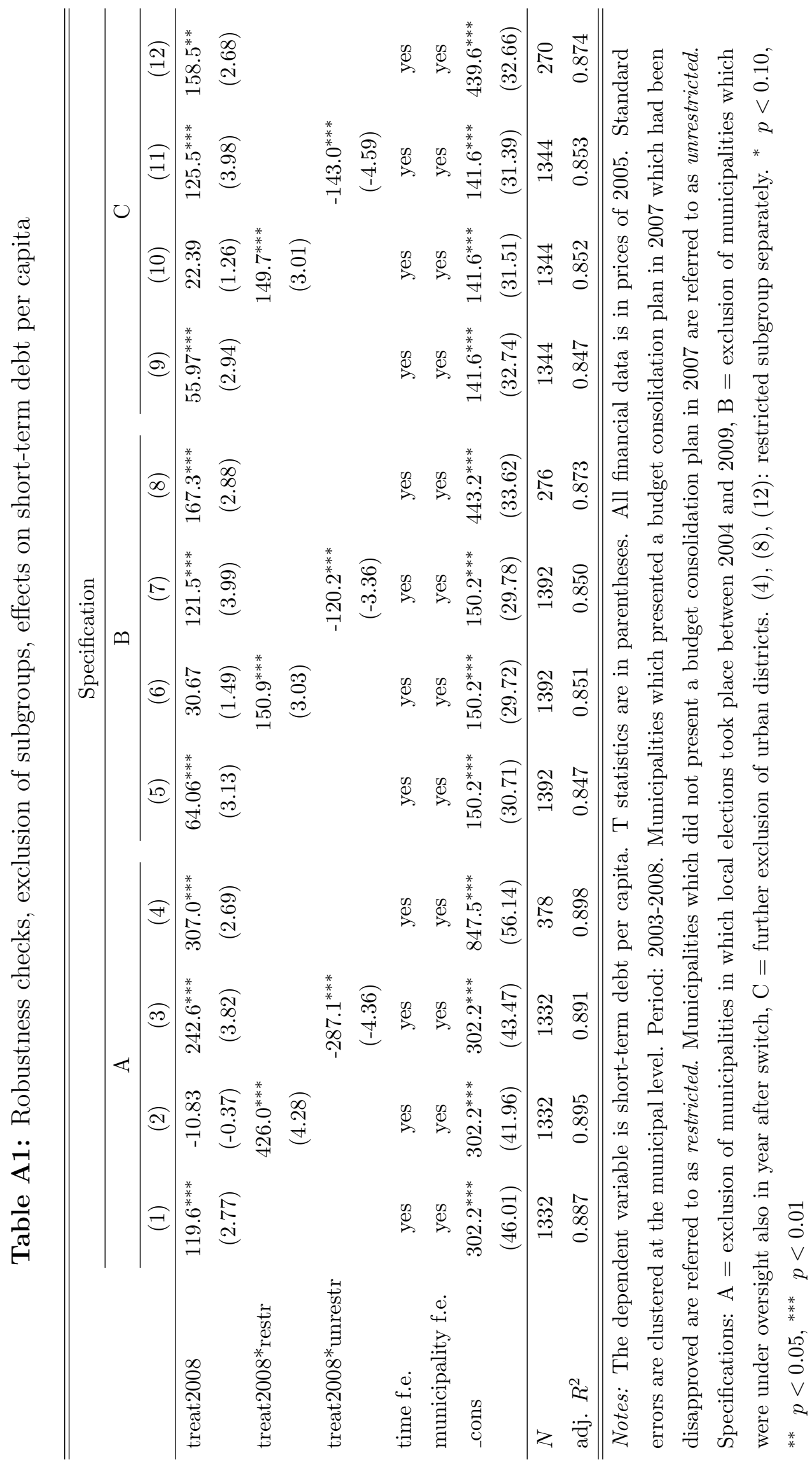




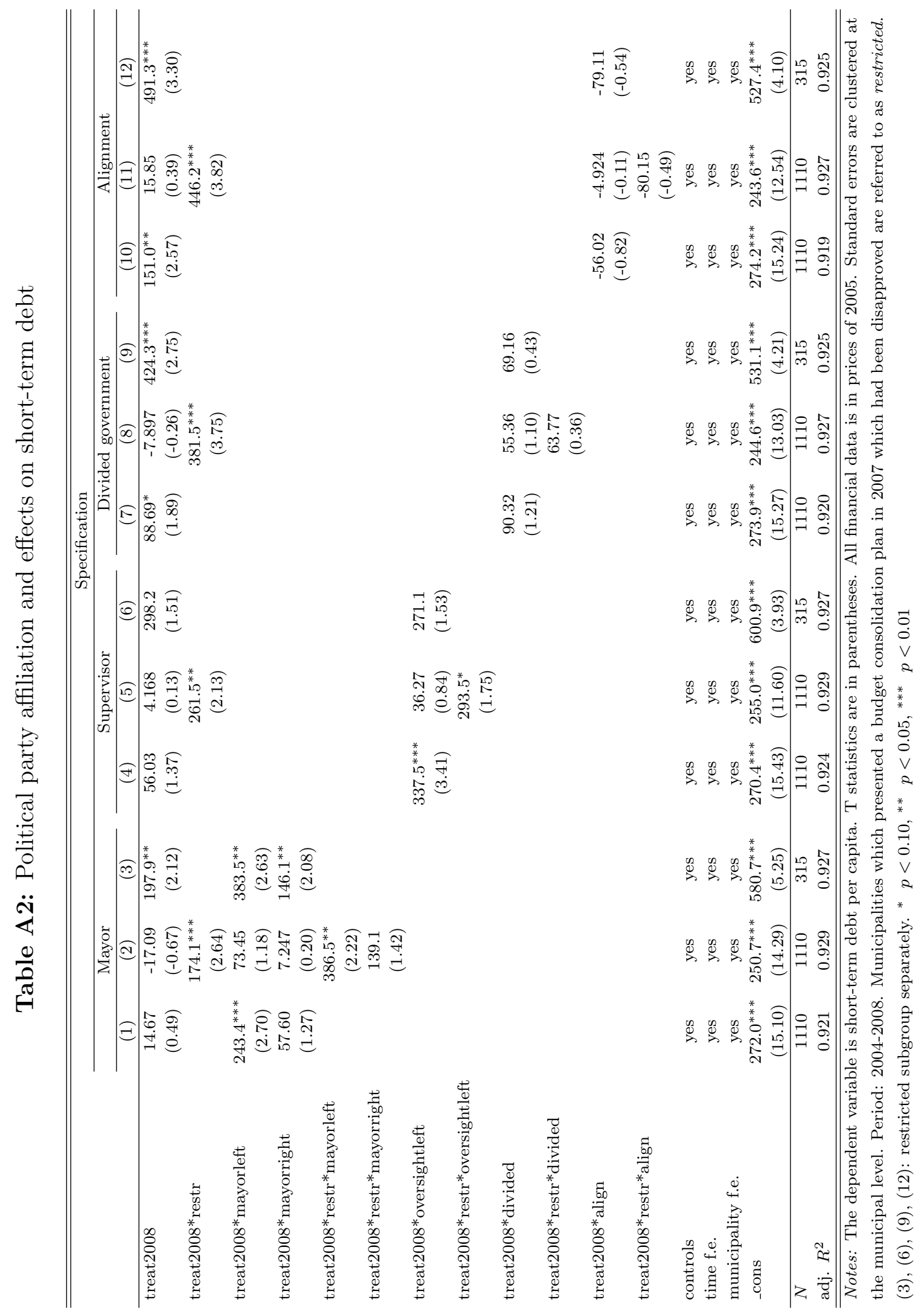

